\title{
Behavioural and Sedative Study in Buffaloes Suffering from Diaphragmatic Hernia Treated with Various NSAIDS
}

\author{
Lokesh $^{1}$, Praveen Kumar ${ }^{1 *}$, Anup Yadav ${ }^{1}$, Ashwanikumar ${ }^{1}$, Rishi Tayal ${ }^{2}$, \\ Rajendra Yadav ${ }^{3}$ and Pankaj Kumar ${ }^{4}$ \\ ${ }^{I}$ Department of Animal Husbandry, Govt. of Haryana, India \\ ${ }^{2}$ Veterinary Surgery and Radiology (LUVAS, Hisar), India \\ ${ }^{3}$ Veterinary Medicine, RVDEC, Mahendergarh (LUVAS, Hisar), India \\ ${ }^{4}$ ADIO, Disease Investigation Lab., Rohtak (LUVAS, Hisar), India \\ *Corresponding author
}

\section{A B S T R A C T}

The study was conducted in eighteen buffaloes categorised into three groups of six animals each. The drugs were used in following combinations: Glycopyrrolate-Xylazine-

\begin{tabular}{|c|}
\hline Keywords \\
\hline $\begin{array}{l}\text { Buffaloes, } \\
\text { NSAIDS, } \\
\text { Diaphragmatic } \\
\text { hernia }\end{array}$ \\
\hline Article Info \\
\hline $\begin{array}{l}\text { Accepted: } \\
\text { 07 November } 2018 \\
\text { Available Online: } \\
\text { 10 December } 2018\end{array}$ \\
\hline
\end{tabular}
Meloxicam-Ketamine, Glycopyrrolate-Xylazine-Tolfenamic acid-Ketamine and Glycopyrrolate-Xylazine-Flunixin-meglumine-Ketamine. Glycopyrrolate was given @ $0.01 \mathrm{mg} / \mathrm{kg}$ body weight i $/ \mathrm{m}$, Xylazine @ $0.04 \mathrm{mg} / \mathrm{kg}$ body weight i $/ \mathrm{m}$, Meloxicam at 0.5 $\mathrm{mg} / \mathrm{kg}$ body weight $\mathrm{i} / \mathrm{m}$, Tolfenamic acid $4 \mathrm{mg} / \mathrm{kg}$ body weight $\mathrm{i} / \mathrm{m}$, Flunixin-meglumine at $2.2 \mathrm{mg} / \mathrm{kg}$ body weight i/v and Xylazine and Ketamine @ $0.04 \mathrm{mg} / \mathrm{kg}$ body weight i/v and $1 \mathrm{mg} / \mathrm{kg}$ body weight $\mathrm{i} / \mathrm{v}$ for induction and maintenance were given. Tolfenamic acid and Flunixin-meglumine groups produced comparable analgesia duration for $40.24 \pm 1.95$ and $43.00 \pm 1.24$ minutes respectively but analgesia duration for Meloxicam group was for $30.34 \pm 2.02$ minutes comparatively lesser than Tolfenamic acid and Flunixin-meglumine groups. Anesthesia remained for comparable duration in Tolfenamic acid group $(59.5 \pm 2.34$ minutes), and Flunixin-meglumine group (58.83 \pm 1.22 minutes) and shorter in Meloxicam group (54.66 \pm 2.45 minutes). Complete recovery was earliest in Meloxicam group in $85.66 \pm 2.02$ minutes followed by Tolfenamic acid group in $91.33 \pm 2.89$ minutes and Flunixin-meglumine group in $93.33 \pm 2.47$ minute.

\section{Introduction}

Diaphramatic hernia is a serious thoracodigestive disorder of buffaloes, in which a part of abdominal viscera "mainly reticulum" passed into the thoracic cavity through a congenital or acquired opening in the diaphragm causing chronic ruminaltympany, anorexia and displacement of the heart
(Radostits et al., 2007). Its high prevalence reported especially from North India. In buffaloes herniation occurs mostly through right ventro-medial part of the diaphragm, which ruptures from the musculo-tendinous junction (Saini et al., 2000). The situation of diaphragmatic hernia is serious, as if it remains untreated causes death in $100 \%$ cases (Krishnamurthy et al., 1985). 
Management of diaphragmatic hernia requires surgery in two stages. The first stage involves a laparo-rumenotomy that enables the surgeon to assess the location and extent of herniation, retract and remove foreign bodies. During the second stage of surgery, the repair of the diaphraghmatic defect is done under general anaesthesia along with controlled ventilation (Singh et al., 2006). There is severe pain during the time of diaphragmatic herniorrhaphy. To achieve anaesthesia and relieve the pain different analgesic drugs are used which act on peripheral and central nervous system.

General anaesthesia is a state of reversible unconsciousness produced by a process of controlled, reversible drug-induced intoxication of the central nervous system in which the patient neither perceives nor recalls noxious stimuli (Hall et al., 2001). It is not easy to select a drug or a combination of drugs for general anaesthesia especially in ruminants. Due to this reason, it becomes imperative to evaluate each sedative or preanaesthetic drug before clinical use.

Glycopyrrolateis a preanaesthetic drug which stimulates cardiac reflex and blocks vagus reflex, thus prevents or inhibits cardiac inhibitory effect of Xylazine. Xylazine administration produces profuse salivation in cattle as recorded by Kumar and Singh (1979). It produced tachycardia (Khan et al., 2007a) in buffalo calves and that it when administered after Xylazine administration caused increased heart rate and mean arterial pressure (Khan et al., 2007b).

Xylazine is typical $\alpha_{2}$-adrenoceptor agonist and exerts its effect accordingly. There is marked variation in susceptibility to Xylazine's effect in various species of domestic animals.

Ketamine is a dissociative anaesthetic that is used for induction/maintenance of anaesthesia in many species. It has the tendency to cause catalepsy and occasional seizers (Pageat, 1986). Propofol was found safe intravenous anaesthetic to induce general anaesthesia in buffaloes (Ratnesh, 2010).

Post-operative pain is commonly managed by Nonsteroidal anti-inflammatory drugs (NSAIDs)/ opioid (Dar et al., 2013). NSAIDs are used extensively in veterinary practice for their analgesic, anti-inflammatory and antipyretic effects. Nonsteroidal antiinflammatory drugs (NSAIDs) have been reported to be extremely effective postoperative analgesics (Mathews, 2001).

Flunixin-meglumine is a carboxylic acid nonsteroidal anti-inflammatory drug and a potent inhibitor of cyclooxygenase (Semrad et al., 1985). In horses, Flunixin-meglumine is indicated for alleviation of inflammation and pain associated with musculoskeletal disorders and visceral pain associated with pain.

Tolfenamic acid belongs to the fenamate group and is a potent inhibitor of cyclooxygenase enzyme. It is efficient in treatment of chronic and acute painful locomoter syndromes in the dog (Lecoindre et al., 1995).

Meloxicam is an oxicam (enolic acid) derivative. Meloxicam has preferential COX-2 activity and is also a mild inhibitor of COX-1 in platelets and kidneys (Deneuche et al., 2004). It is indicated for the management of inflammation and pain arising from acute and chronic diseases (Lascelles et al., 2001).

Meloxicam, Tolfenamic acid and Flunixinmeglumine have not been tried earlier as preemptive analgesia in combination with Glycopyrrolate - Xylazine - Ketamine anaesthesia in buffaloes undergoing diaphragmatic harniorrhaphy (D.H.). Therefore, the present study was undertaken to evaluate the behavioural and sedative study in buffalo treated with the following drugs: 
Group1 Glycopyrrolate - Xylazine Meloxicam - Ketamine in buffaloes undergoing diaphragmatic herniorrhaphy.

Group2 Glycopyrrolate - Xylazine Tolfenamic acid - Ketamine in buffaloes undergoing diaphragmatic herniorrhaphy.

Group 3 Glycopyrrolate -Xylazine - Flunixinmeglumine - Ketamine in buffalo undergoing diaphragmatic herniorrhaphy.

\section{Materials and Methods}

Eighteen clinical cases of buffaloes suffering from diaphramatic hernia presented to the Teaching Veterinary Clinical Complex, LUVAS, Hisar were taken in consideration for present study.

Diaphragmatic hernia was confirmed by radiography and rumenotomy. In positive cases, the ruminal contents were evacuated completely by laparo-rumenotomy and thereafter diaphragmatic hernia repair was done under general anaesthesia. Each animal was weighed before the diaphragmatic herniorraphy for calculating the proper dose of drugs used for general anaesthesia and kept off feed and water after laparo-rumenotomy and these animals were kept strictly on fluid therapy to avoid regurgitation during operation.

The animals were divided into three groups of six animals each. Pilot trials were done to standardize the dose rates and route of administration of different drugs.

Rectal temperature, heart rate (by auscultation) and respiration rate were recorded just before administration of the $\operatorname{drug}(\mathrm{s})$ along with the ambient temperature to form the base values. The blood samples were collected from jugular venipuncture before rumenotomy i.e before administration of the drugs, before diaphragmatic herniorraphy, 15 minutes after administration of Meloxicam/ Tolfenamic acid/ Flunixin-meglumine, 5 minutes after administration of Ketamine, after complete recovery from the effects of the drugs and at 24 hour after recovery. Various physiological parameters were recorded at before rumenotomy, before diaphragmatic herniorrhaphy, 15 minutes after Glycopyrrolate, 10 minutes after Xylazine, and 15 minutes after Meloxicam/Tolfenamic acid/Flunixin-meglumine administeration at recovery and 24 hours after diaphragmatic herniorrhaphy.

The animals were observed to record the following behavioral and sedative changes:

1. Spontaneous motor activity

2. Onset of salivation, urination, defaecation and lacrimation

3. Weak time: time elapsed from administration of drug to onset of ataxia.

4. Qualitative and subjective analgesic effect(s) of drugs were judged by observing physical response of the medicated animal to pin prick/surgical response.

5. Recovery from effects of drugs was interpreted to have occurred as exhibited by:

a. Sternal recumbency and head rightening reflex

b. Standing time with ataxia.

Complete recovery without ataxia.

\section{Results and Discussion}

The study was conducted on eighteen clinical cases of diaphragmatic hernia presented in TVCC, Hisar and these were divided into three groups of six animals each. All the parameters listed below were observed/ recorded before the animals were operated for rumenotomy and were taken as base values. The results of study are presented in the following tables (Table 1-4). 
Table.1 Group 1: Means and standard errors $( \pm)$ in time format of minutes for different behavioural characteristics of onset of CNS depression and recovery from CNS depression induced by administration of Glycopyrrolate-Xylazine-Meloxicam-Ketamine combination

\begin{tabular}{|c|c|c|c|}
\hline Reflexes & & $\begin{array}{l}\text { Mean time } \\
\text { (minutes) }\end{array}$ & $\begin{array}{c}\text { Standard } \\
\text { error }( \pm)\end{array}$ \\
\hline $\begin{array}{l}\text { Muzzle dryness(after Glycopyrrolate } \\
\text { administration) }\end{array}$ & & 14 & 1.15 \\
\hline $\begin{array}{l}\text { Decreased spontaneous motor activity } \\
\text { (SMA) (after Xylazine injection) }\end{array}$ & & 7.33 & 0.55 \\
\hline Ataxia /weak time (after Xylazine injection) & & 14.16 & 0.54 \\
\hline \multirow{2}{*}{$\begin{array}{lll}\text { Swallowing } & \text { reflex(after } & \text { Ketamine } \\
\text { administration) }\end{array}$} & Loss & 2.33 & 0.24 \\
\hline & Regain & 53.83 & 1.40 \\
\hline $\begin{array}{l}\text { Regaining of Spontaneous respiration } \\
\text { (after Ketamine administration) }\end{array}$ & & 39.66 & 2.66 \\
\hline \multirow{4}{*}{$\begin{array}{l}\text { Onset of analgesia (after Ketamine } \\
\text { administration) }\end{array}$} & Fetlock & 2 & 0.22 \\
\hline & Base of Horn & 3.75 & 0.30 \\
\hline & Ribs & 4.66 & 0.33 \\
\hline & Tail & 3.08 & 0.20 \\
\hline \multirow{4}{*}{$\begin{array}{l}\text { Loss of analgesia (after Ketamine } \\
\text { administration) }\end{array}$} & Fetlock & 41.83 & 2.40 \\
\hline & Base of Horn & 38 & 2.36 \\
\hline & Ribs & 35 & 2.35 \\
\hline & Tail & 37 & 2.26 \\
\hline $\begin{array}{l}\text { Regaining of head rightening reflex (after } \\
\text { Ketamine administration) }\end{array}$ & & 54.66 & 2.45 \\
\hline $\begin{array}{l}\text { Return to sternal recumbency (after } \\
\text { Ketamine administration) }\end{array}$ & & 61.66 & 2.17 \\
\hline $\begin{array}{l}\text { Standing time with ataxia (after Ketamine } \\
\text { administration) }\end{array}$ & & 72.66 & 2.67 \\
\hline $\begin{array}{l}\text { Complete recovery (after Ketamine } \\
\text { administration) }\end{array}$ & & 85.66 & 2.02 \\
\hline
\end{tabular}


Table. 2 Group:2 Means and standard errors $( \pm)$ in time format of minutes for different behavioural characteristics of onset of CNS depression and recovery from CNS depression induced by administration of Glycopyrrolate-Xylazine-Tolfenamic acid-Ketamine combination

\begin{tabular}{|c|c|c|c|}
\hline Reflexes & & $\begin{array}{l}\text { Mean time } \\
\text { (minutes) }\end{array}$ & $\begin{array}{l}\text { Standard } \\
\text { error }( \pm)\end{array}$ \\
\hline $\begin{array}{l}\text { Muzzle dryness (after Glycopyrrolate } \\
\text { administration) }\end{array}$ & & 14.83 & 1.10 \\
\hline $\begin{array}{l}\text { Decreased spontaneous motor activity } \\
\text { (SMA) (after Xylazine injection) }\end{array}$ & & 8.66 & 0.88 \\
\hline $\begin{array}{l}\text { Ataxia /weak time (after Xylazine } \\
\text { injection) }\end{array}$ & & 14.83 & 0.87 \\
\hline \multirow[t]{2}{*}{$\begin{array}{l}\text { Swallowing reflex (after Ketamine } \\
\text { administration) }\end{array}$} & Loss & 2.16 & 0.27 \\
\hline & Regain & 61.66 & 2.20 \\
\hline $\begin{array}{l}\text { Regaining of Spontaneous respiration } \\
\text { (after Ketamine administration) }\end{array}$ & & 43.66 & 3.52 \\
\hline \multirow{4}{*}{$\begin{array}{l}\text { Onset of analgesia (after Ketamine } \\
\text { administration) }\end{array}$} & Fetlock & 2.33 & 0.21 \\
\hline & $\begin{array}{l}\text { Base of } \\
\text { Horn }\end{array}$ & 4.16 & 0.65 \\
\hline & Ribs & 5.5 & 0.61 \\
\hline & Tail & 3.08 & 0.41 \\
\hline \multirow{4}{*}{$\begin{array}{l}\text { Loss of analgesia (after Ketamine } \\
\text { administration) }\end{array}$} & Fetlock & 50.5 & 2.43 \\
\hline & $\begin{array}{l}\text { Base of } \\
\text { Horn }\end{array}$ & 50.33 & 2.83 \\
\hline & Ribs & 45.5 & 2.56 \\
\hline & Tail & 49.5 & 2.90 \\
\hline $\begin{array}{l}\text { Regaining of head rightening reflex (after } \\
\text { Ketamine administration) }\end{array}$ & & 59.5 & 2.34 \\
\hline $\begin{array}{l}\text { Return to sternal recumbency (after } \\
\text { Ketamine administration) }\end{array}$ & & 66.33 & 2.02 \\
\hline $\begin{array}{l}\text { Standing time with ataxia (after Ketamine } \\
\text { administration) }\end{array}$ & & 76.16 & 2.15 \\
\hline $\begin{array}{l}\text { Complete recovery (after Ketamine } \\
\text { administration) }\end{array}$ & & 91.33 & 2.89 \\
\hline
\end{tabular}


Table.3 Group:3 Means and standard errors $( \pm)$ in time format of minutes for different behavioural characteristics of onset of CNS depression and recovery from CNS depression induced by administration of Glycopyrrolate-Xylazine-Flunixin-meglumine-Ketamine combination

\begin{tabular}{|c|c|c|c|}
\hline Reflexes & & $\begin{array}{l}\text { Mean time } \\
\text { (minutes) }\end{array}$ & $\begin{array}{l}\text { Standard } \\
\text { error }( \pm)\end{array}$ \\
\hline $\begin{array}{l}\text { Muzzle dryness (after Glycopyrrolate } \\
\text { administration) }\end{array}$ & & 15.83 & 1.24 \\
\hline $\begin{array}{l}\text { Decreased spontaneous motor activity (SMA) } \\
\text { (after Xylazine injection) }\end{array}$ & & 8.05 & 0.23 \\
\hline Ataxia /weak time(after Xylazine injection) & & 15.5 & 0.84 \\
\hline \multirow[t]{2}{*}{$\begin{array}{llll}\text { Swallowing } & \text { reflex } & \text { (after } & \text { Ketamine } \\
\text { administration) }\end{array}$} & Loss & 2 & 0.28 \\
\hline & Regain & 61.66 & 2.64 \\
\hline $\begin{array}{l}\text { Regaining of Spontaneous respiration (after } \\
\text { Ketamine administration) }\end{array}$ & & 49 & 9.59 \\
\hline \multirow{4}{*}{$\begin{array}{l}\text { Onset of analgesia (after Ketamine } \\
\text { administration) }\end{array}$} & Fetlock & 3 & 0.34 \\
\hline & $\begin{array}{l}\text { Base of } \\
\text { Horn }\end{array}$ & 4.66 & 0.42 \\
\hline & Ribs & 6.66 & 0.42 \\
\hline & Tail & 3.33 & 0.21 \\
\hline \multirow{4}{*}{$\begin{array}{l}\text { Loss of analgesia (after Ketamine } \\
\text { administration) }\end{array}$} & Fetlock & 52.5 & 1.87 \\
\hline & $\begin{array}{l}\text { Base of } \\
\text { Horn }\end{array}$ & 52.5 & 2.14 \\
\hline & Ribs & 49.66 & 1.66 \\
\hline & Tail & 48.33 & 0.84 \\
\hline $\begin{array}{l}\text { Regaining of head rightening reflex (after } \\
\text { Ketamine administration) }\end{array}$ & & 58.83 & 1.22 \\
\hline $\begin{array}{l}\text { Return to sternal recumbency (after Ketamine } \\
\text { administration) }\end{array}$ & & 63.33 & 1.14 \\
\hline $\begin{array}{l}\text { Standing time with ataxia (after Ketamine } \\
\text { administration) }\end{array}$ & & 78.83 & 1.83 \\
\hline $\begin{array}{l}\text { Complete recovery } \\
\text { administration) }\end{array}$ & & 93.33 & 2.47 \\
\hline
\end{tabular}


Table.4 Means and standard errors $( \pm)$ in time format of minutes for different behavioural characteristics of different groups

\begin{tabular}{|c|c|c|c|c|}
\hline Reflexes & & $\begin{array}{c}\text { Mean } \\
\text { time } \\
\text { (minutes) } \\
\text { GXMK }\end{array}$ & $\begin{array}{c}\text { Mean } \\
\text { time } \\
\text { (minutes) } \\
\text { GXTAK }\end{array}$ & $\begin{array}{c}\text { Mean } \\
\text { time } \\
\text { (minutes) } \\
\text { GXFMK }\end{array}$ \\
\hline $\begin{array}{l}\text { Muzzle dryness(after Glycopyrrolate } \\
\text { administration) }\end{array}$ & & $14 \pm 1.15$ & $14.83 \pm 1.10$ & $15.83 \pm 1.24$ \\
\hline $\begin{array}{l}\text { Decreased spontaneous motor activity } \\
\text { (SMA) (after Xylazine injection) }\end{array}$ & & $7.33 \pm 0.55$ & $8.66 \pm 0.88$ & $8.05 \pm 0.23$ \\
\hline Ataxia /weak time (after Xylazine injection) & & $14.16 \pm 0.54$ & $14.83 \pm 0.83$ & $15.5 \pm 0.84$ \\
\hline \multirow[t]{2}{*}{$\begin{array}{l}\text { Swallowing reflex (after Ketamine } \\
\text { administration) }\end{array}$} & Loss & $2.33 \pm 0.24$ & $2.16 \pm 0.27$ & $2.00 \pm 0.28$ \\
\hline & Regain & $53.83 \pm 1.40$ & $61.66 \pm 2.20$ & $61.66 \pm 2.64$ \\
\hline $\begin{array}{l}\text { Regaining of Spontaneous respiration } \\
\text { (after Ketamine administration) }\end{array}$ & & $39.66 \pm 2.66$ & $43.66 \pm 3.52$ & $49 \pm 9.59$ \\
\hline \multirow[t]{4}{*}{$\begin{array}{l}\text { Onset of analgesia (after Ketamine } \\
\text { administration) }\end{array}$} & Fetlock & $2.00 \pm 0.22$ & $2.33 \pm 0.21$ & $3.00 \pm 0.34$ \\
\hline & $\begin{array}{l}\text { Base of } \\
\text { Horn }\end{array}$ & $3.75 \pm 0.30$ & $4.16 \pm 0.65$ & $4.66 \pm 0.42$ \\
\hline & Ribs & $4.66 \pm 0.33$ & $5.5 \pm 0.61$ & $6.66 \pm 0.42$ \\
\hline & Tail & $3.08 \pm 0.20$ & $3.08 \pm 0.41$ & $3.33 \pm 0.21$ \\
\hline \multirow[t]{4}{*}{$\begin{array}{l}\text { Loss of analgesia (after Ketamine } \\
\text { administration) }\end{array}$} & Fetlock & $41.83 \pm 2.40$ & $50.5 \pm 2.43$ & $52.5 \pm 1.85$ \\
\hline & $\begin{array}{l}\text { Base of } \\
\text { Horn }\end{array}$ & $38.00 \pm 2.36$ & $50.33 \pm 2.83$ & $52.5 \pm 2.14$ \\
\hline & Ribs & $35.00 \pm 2.35$ & $45.5 \pm 2.56$ & $49.66 \pm 1.66$ \\
\hline & Tail & $37 \pm 2.26$ & $49.5 \pm 2.90$ & $48.33 \pm 0.84$ \\
\hline $\begin{array}{l}\text { Regaining of head rightening reflex (after } \\
\text { Ketamine administration) }\end{array}$ & & $54.66 \pm 2.45$ & $59.5 \pm 2.34$ & $58.83 \pm 1.22$ \\
\hline $\begin{array}{l}\text { Return to sternal recumbency (after } \\
\text { Ketamine administration) }\end{array}$ & & $61.66 \pm 2.17$ & $66.33 \pm 2.02$ & $63.33 \pm 1.14$ \\
\hline $\begin{array}{l}\text { Standing time with ataxia (after Ketamine } \\
\text { administration) }\end{array}$ & & $72.66 \pm 2.67$ & $76.16 \pm 2.15$ & $78.83 \pm 1.83$ \\
\hline $\begin{array}{l}\text { Complete recovery (after Ketamine } \\
\text { administration) }\end{array}$ & & $85.66 \pm 2.02$ & $91.33 \pm 2.89$ & $93.33 \pm 2.47$ \\
\hline
\end{tabular}




\section{Group 1}

CNS depression was observed after intramuscular administration of Xylazine as all the animals showed decrease in spontaneous motor activity at $7.33 \pm 0.55$ minutes, ataxia at $13.5 \pm 1.47$ minutes followed by lateral recumbency. In cattle administration of Xylazine $(0.5 \mathrm{mg} / \mathrm{kg}, \mathrm{IM})$ produced deep sedation with animal going into lateral recumbency (Hall and Clarke, 1969). Dropping of head and ataxia was seen in horses given premedication with Xylazine (Butera et al., 1980). A moderate amount of salivation with good sedation and muscle relaxation was observed following Xylazine administration in buffalo calves (Peshin and Kumar, 1979). Palpebral and corneal reflexes and tongue movements (curling) were abolished in four animals during the period of anaesthesia. Swallowing reflex was abolished after 2.33 \pm 0.24 minutes of Ketamine administration. This finding holds well to the findings in goats given an intravenous dose of midazolam followed by Ketamine (Singh, 2004) and by Kumar and Thurmon (1977), in goats given acepromazine-Ketamine anasesthesia and by Singh (2008) in buffalo calves given an intravenous dose of Xylazine and Ketamine, but the findings are contrary with the reports of Ghanawat and Mantra, (1996) in cats given Xylazine-Ketamine and in buffalo calves given Ketamine @ 2.0 $\mathrm{mg} / \mathrm{kg}$ by intravenous drip, Ketamine anaesthesia showed intact palpebral and corneal reflexes. There was complete analgesia at fetlock, base of tail, abdomen, ribs periosteum and base of horn after administration of Ketamine. Analgesia remained for $30.34 \pm 2.02$ minutes at ribs periosteum. Leece et al., (2005) concluded that meloxicam provided satisfactory analgesia for 72 hours following ovariohysterectomy in dogs. Post-operative analgesic effect of Meloxicam and Butorphanol were considered adequate in
African buffaloes following MidazolamKetamine-Isoflurane anaesthesia (Stegmann, 2004). Pre-operative administration of meloxicam immediately before induction was also found safe and effective method of controlling post operative pain for upto 24 hours in dogs (Mathews 2001 and Deneuche et al., 2004). Mathews et al., (2001) studied the analgesic efficacy of meloxicam after various soft tissue surgical procedures and reported that meloxicam provides excellent analgesia for upto 24 hours after administration as compared to Butorphenol.

Anaesthesia remained for a mean time of $54.66 \pm 2.45$ minutes. Ketamine provides profound analgesia (Evers and Crowder, 2001) and agrees with findings in calves given intravenous Xylazine-Ketamine (Singh, 2008); in goats given midazolam-Ketamine intravenously (Singh, 2004). Singh (2004) reported that good analgesia commenced 5 minutes after Ketamine administration and remained till 30 minutes. In present study head rightening reflex was observed at $54.66 \pm 2.45$ minutes indicating the start of recovery period followed by sternal recumbency at $61.66 \pm 2.17$ minutes and standing of animals with ataxia occurred at $72.66 \pm 2.67$ minutes with complete recovery without ataxia at $85.66 \pm 2.02$ minutes of Ketamine injection.

\section{Group 2}

Onset of CNS depression started after intramuscular administration of Xylazine as all the animals showed decrease in spontaneous motor activity at $8.66 \pm 0.88$ minutes, ataxia at $14.83 \pm 0.87$ minutes followed by lateral recumbency. In cattle administration of Xylazine $(0.5 \mathrm{mg} / \mathrm{kg}, \mathrm{IM})$ produced deep sedation with animal going into lateral recumbency (Hall and Clarke, 1969). Dropping of head and ataxia was seen in horses given premedication with Xylazine 
(Butera et al., 1980). Onset of salivation was observed in two animals. A moderate amount of salivation with good sedation and muscle relaxation was observed following Xylazine administration in buffalo calves (Peshin and Kumar, 1979). Palpebral and corneal reflexes and tongue movements (curling) were abolished in two animals during the period of anaesthesia. Swallowing reflex was abolished after 2.16 \pm 0.27 minutes of Ketamine administration. This finding holds well to the findings in goats given an intravenous dose of midazolam followed by Ketamine (Singh, 2004) and by Kumar and Thurmon (1977), in goats given acepromazine-Ketamine anaesthesia and by Singh (2008) in buffalo calves given an intravenous dose of Xylazine and Ketamine, but the findings are contrary with the reports of Ghanawat and Mantra, (1996) in cats given Xylazine-Ketamine and in buffalo calves given Ketamine @ 2.0 $\mathrm{mg} / \mathrm{kg}$ by intravenous drip, Ketamine anaesthesia showed intact palpebral and corneal reflexes. There was complete analgesia at fetlock, base of tail, abdomen, ribs periosteum and base of horn after administration of Ketamine. Analgesia remained for $40.24 \pm 1.95$ minutes at ribs periosteum. Tolfenamic acid was found effective for post operative analgesia in dogs undergoing orthopaedic surgery (Grandemange et al., 2007).

Anaesthesia remained for a mean time of $59.5 \pm 2.34$ minutes. Ketamine provides profound analgesia (Evers and Crowder, 2001) and agrees with findings in calves given intravenous Xylazine-Ketamine (Singh, 2008); in goats given midazolam-Ketamine intravenously (Singh, 2004). Singh (2004) reported that good analgesia commenced 5 minutes after Ketamine administration and remained till 30 minutes. In present study head rightening reflex was observed at $59.5 \pm 2.34$ minutes indicating the start of recovery period followed by sternal recumbency at $66.33 \pm 2.02$ minutes and standing of animals with ataxia occurred at $76.16 \pm 2.15$ minutes with complete recovery without ataxia at $91.33 \pm 2.89$ minutes of Ketamine injection.

\section{Group 3}

After intramuscular administration of Xylazine CNS depression was observed as all the animals showed decrease in spontaneous motor activity at $8.05 \pm 0.23$ minutes, ataxia at $15.5 \pm 0.84$ minutes followed by lateral recumbency. In cattle administration of Xylazine $(0.5 \mathrm{mg} / \mathrm{kg}$, IM) produced deep sedation with animal going into lateral recumbency (Hall and Clarke, 1969). Dropping of head and ataxia was seen in horses given premedication with Xylazine (Butera et al., 1980). Onset of salivation was observed in two animals. A moderate amount of salivation with good sedation and muscle relaxation was observed following Xylazine administration in buffalo calves (Peshin and Kumar, 1979). Palpebral and corneal reflexes and tongue movements (curling) were observed in four animals during the period of anaesthesia. Swallowing reflex was abolished after 2.16 \pm 0.27 minutes of Ketamine administration. This finding holds well to the findings in goats given an intravenous dose of midazolam followed by Ketamine (Singh, 2004) and by Kumar and Thurmon (1977), in goats given acepromazine-Ketamine anaesthesia and by Singh (2008) in buffalo calves given an intravenous dose of Xylazine and Ketamine, but the findings are contrary with the reports of Ghanawat and Mantra, (1996) in cats given Xylazine-Ketamine and in buffalo calves given Ketamine @ 2.0 $\mathrm{mg} / \mathrm{kg}$ by intravenous drip, Ketamine anaesthesia showed intact palpebral and corneal reflexes. There was complete analgesia at fetlock, base of tail, abdomen, ribs periosteum and base of horn after administration of Ketamine. Analgesia 
remained for $43 \pm 1.24$ minutes at ribs periosteum. In horses, Flunixin-meglumine is indicated for alleviation of inflammation and pain associated with musculoskeletal disorders and visceral pain associated with colic. Flunixin-meglumine is a drug that is approved by US Food and Drug Administration for therapy for colic and musculoskeletal disorders (Houdeshell and Hennessey, 1977; Vernilimer and Hennessey, 1977). Anaesthesia remained for a mean time of $58.83 \pm 1.22$ minutes. Ketamine provides profound analgesia (Evers and Crowder, 2001) and agrees with findings in calves given intravenous Xylazine-Ketamine (Singh, 2008); in goats given midazolam-Ketamine intravenously (Singh, 2004). Singh (2004) reported that good analgesia commenced 5 minutes after Ketamine administration and remained till 30 minutes. In present study head rightening reflex was observed at $58.83 \pm 1.22$ minutes indicating the start of recovery period followed by sternal recumbency at $63.33 \pm 1.14$ minutes and standing of animals with ataxia occurred at $78.83 \pm 1.83$ minutes with complete recovery without ataxia at $93.33 \pm 2.47$ minutes of Ketamine injection.

\section{References}

Butera, S. T., Garner, H. E., Moore, J. N. and Ahmed, J. F. 1980. Xylazine /sodium thiopental combination for short term anaesthesia in horses.VM SAC.75(5): 765768.

Dar, S. H., Bhadwal, M. S. and Zama, M. M. S. 2013. Post-operative analgesia in dogs by Tramadol and Nimesulide. Indian Vet. J., 90(2): 32-34.

Deneuche, A. J., Dufayet, C., Goby L., Fayolle, P. and Desbois, C. 2004.Analgesic comparison of meloxicam and ketoprofen for orthopedic surgery in dogs. Vet. Surg. 33: 650-660.

Evers, A. S. and Crowder, C. M. 2001. General Anaesthetics. In: Goodman and Gilman's
The Pharmacological Basis of Therapeutics. (Hardman, J.G. and Limberd, L.E. eds). McGrawhill Medical Publishing Division. New York. pp.339427.

Ghanawat, H. G. and Mantra, M. B. 1996. Ketamine-xylazine and ketamine diazepam anaesthesia in cats. Indian Vet. J.73(2): 184-187.

Grandemange, E., Fournel, S. and Boisramé, B., 2007 Field evaluation of the efficacy of tolfenamic acid administered in one single preoperative injection for the prevention of the postoperative pain in the dog. J. Vet. Pharmacol. Therap., 30: 503507.

Hall, L. W. and Clarke, K. W. 1969. "Xylazine"- a new sedative for horses and cattle. Vet. Rec.85: 512-517.

Hall, L. W., Clarke, K. W. and Trim, C. M. 2001.Principle of sedation, analgesia and premedication. In: Veterinary Anaesthesia. $10^{\text {th }}$ edn. W. B. Saunders, London.

Houdeshell, J. W., Hennessey, P. W. 1977 A new non-steroidal, anti-inflammatory analgesic for horses. J. Equine Med. Surg.1(2): 57-63.

Khan, I., Kumar, A., Singh, J., Peshin, P.K. and Singh, S. 2007 b. Evaluation of glycopyrrolate-xylazine as a sedative in buffalo calves (Bubalus bubalis). Italian J. Anim. Sci.6(2): 1011-1014.

Khan, I., Kumar, A; Singh, J; Peshin, P.K. and Singh, S. 2007 a. Evaluation of glycopyrrotate as an anticholinergic in buffalo calves (Bubalus bubalis). Italian J. Anim. Sci. 6(2): 1007-1010.

Krishnamurthy, D., Nigam, J. M., Peshin, P. K., Sharma, D. N., and Tyagi, R. P. S. 1985. Monograph on diaphragmatic hernia in bovines. Directorate of Publications, Haryana Agricultural University, Hisar, India.

Kumar, A and Singh, H. P. 1979. Ketamine and xylazine anaesthesia in bovine paediatric surgery. Indian Vet. J.56(3): 219-222.

Kumar, A. and Thurmon, J. C. 1977. A note on 
anaesthetic effects of mixture of acepromazine and ketamine hydrochloride in goats. Indian J. Anim. Sci. 47:601-604.

Lascelles, B. D. X., Henderson, A. J. and Hackett, I. J. 2001. Evaluation of the clinical efficacy of meloxicam in cats with painful locomotor disorders. J. Small Anim. pract. 42: 587-593.

Lecoindre, P.,Thomas, E. and Richard, P. (1995). Evaluation of new therapeutic regimen of tolfenamic acid in the treatment chronic painful locomotor syndromes in dog. Proceedings of $2^{\text {nd }}$ European Congress of the Federation of European companin Animal Veterinary Associationsp. 123, Brussels 27-29 Oct 1995.

Mathews, K. A. 2001 Perioperative use of nonsteroidal anti-inflammatory analgesics. Proceedings World Small Animal Vet. Assoc. Congress. (WSAVA-2001).

Pageat, P. 1986. Clinical study of recurrent hallucination after ketamine anaesthesia in dogs and cats: 39 cases. Pratique Medicale and Chirugicale de l' Animal de Compagnie. 21 :185-190.

Peshin, P. K. and Kumar, A. 1979. Physiologic and sedative effects of xylazine in buffaloes. Indian Vet. J. 56: 864-871.

Radostits, O.M., Gay, C.C., Blood, D.C. and Hinchcliff, K.W. (2007). Veterinary Medicine: A Textbook of the Diseases of Cattle, Sheep, Pigs, Goats and Horses. 10th ed. London, England: WB Saunders: 923-937.

Ratnesh, 2010. Evaluation of Propofol as intravenous anaesthetic to induce general anaesthesia in buffalo calves. MVSc Thesis, CCS Haryana Agricultural University, Hisar.

Saini, N. S., Sobti, V. K., Mirakhur, K. K., Singh, S. S., Singh, K. I., Bansal, P. S., Singh, P. S. and Bhatia, R. 2000. Retrospective evaluation of 80 nonsurviving buffaloes with diaphragmatic hernia. Vet. Rec. 147: 275-276.

Semrad, S. D., Hardee, G. E., Hardee, M. M. 1985. Flunixin-meglumine given in small doses: pharmacokinetics and prostaglandin inhibition in healthy horses. Am. J. Vet. Res., 46: 2474-2479.

Singh, J., Fazili, M. R., Chawla, S. K., Tayal, R. ; Behl, S. M. and Singh, S. 2006. Current status of diaphraghmatic hernia in buffaloes with special reference to etiology and treatment: a review. Indian J. Vet. Surg. 27(2): 73-79.

Singh, K. 2004. Evaluation of ketamine as an anaesthetic in goats. (Capra hircus) with midazolam premedication. MVSc Thesis. Hisar: CCS Haryana Agricultural University.

Singh, S. 2008. Evaluation of atropineacepromazine - xylazine - ketamine andglycopyrrolate - acepromazinexylazine-ketamine combinations as anaestheitics in buffalo calves. MVSc. Thesis. Hisar: CCS Haryana Agricultural University.

Vernilimer, C. D. and Hennessy, P. W. 1977. Clinical studies on Flunixin-meglumine in the treatment of equine colic. $J$ Equine. Med. Surg.1: 111-116.

\section{How to cite this article:}

Lokesh1, Praveen Kumar, Anup Yadav, Ashwanikumar, Rishi Tayal, Rajendra Yadav and Pankaj Kumar. 2018. Behavioural and Sedative Study in Buffaloes Suffering from Diaphragmatic Hernia Treated with Various Nsaids. Int.J.Curr.Microbiol.App.Sci. 7(12): 665675. doi: https://doi.org/10.20546/ijcmas.2018.712.083 